\title{
Characterization of thermally stable gamma alumina fibres biomimicking sisal
}

Mónica Benítez-Guerrero ${ }^{a}{ }^{*}$, Luís A. Pérez-Maqueda ${ }^{\mathrm{b}}$, Pedro E. Sánchez-Jiménez ${ }^{\mathrm{b}}$ and José Pascual$\operatorname{Cosp}^{\mathrm{a}}$.

\author{
a Departamento de Ingeniería Civil, Materiales y Fabricación, Universidad de Málaga, C. Dr. Ortiz Ramos s/n, 29071 \\ Málaga, Spain. \\ ${ }^{\mathrm{b}}$ Instituto de Ciencia de Materiales de Sevilla, CSIC-Universidad de Sevilla, C. Américo Vespucio 49, 41092 Sevilla, \\ Spain \\ * Corresponding author, Address: Departamento de Ingeniería Civil, Materiales y Fabricación, Universidad de \\ Málaga, C. Dr. Ortiz Ramos s/n, 29071 Málaga, Spain. Tel.: +34951952594. E-mail address: \\ monica_benitez_guerrero@yahoo.es
}

\begin{abstract}
Mesoporous gamma alumina fibres of high surface area, stable up to $1000{ }^{\circ} \mathrm{C}$, were synthesized by bioreplica technique using sisal fibres as templates. Alumina formation during pyrolysis and calcination of fibres infiltrated with aluminium chloride solution has been studied, paying special attention to the interaction between the precursor and sisal fibres, using several experimental techniques such as ATR-FTIR, coupled TG-FTIR and thermo-XRD analysis. The morphology and microstructure of the resulting alumina fibres were characterized using SEM and TEM. The crystallographic analysis of the alumina sample performed by electron and Xray diffraction suggests that fibres are constituted by $\eta$ and $\gamma-\mathrm{Al}_{2} \mathrm{O}_{3}$ crystallites, whose chemical structure was confirmed by ATR-FTIR and $\mathrm{Al}^{27}$-MAS-NMR. The specific surface area and porosity of ceramic fibres were determined by $\mathrm{N}_{2}$ and $\mathrm{CO}_{2}$ adsorption-desorption measurements. Resulting alumina fibres retain high specific surface areas of $200 \mathrm{~m}^{2} / \mathrm{g}$ and 150 $\mathrm{m}^{2} / \mathrm{g}$ even after calcination at $1000{ }^{\circ} \mathrm{C}$ for $15 \mathrm{~h}$ in dry air and for $4 \mathrm{~h}$ in wet air, respectively.
\end{abstract}

Keywords: biomorphic alumina; biomimetic alumina; inorganic salt infiltration; sisal fibre biotemplate. 


\section{Introduction}

High surface area mesoporous aluminas with narrow pore distribution have been the subject of extensive research employing different strategies [1]. However, the synthesis of aluminas with hierarchically ordered pore structure attracts more and more attention $[2,3]$, due to the highly effective transport phenomena and the easy diffusion of reactants and products when pores of different sizes are interconnected. Generation of controllable hierarchical pores has been fundamentally carried out through agents acting as porosity generators like organic additives and surfactants $[4,5]$, foams, emulsions or masks based on replica procedure [6], as well as by using others methods as hydrothermal treatment [7], and recently, nanocasting technique [8]. In any case, most of the employed processes generally involve the use of expensive porosity agents which must be finally removed by extraction or calcination.

A method of ceramic synthesis that has attracted significant attention in the scientific community is the variant of the infiltration-replica technique which uses natural masks or biotemplates [9-11]. Through bio-replica, it is possible to generate ceramic materials which faithfully reproduce the morphology and structure of the starting preforms in an easy way, with a porous architecture scaled from nano-, micro- to macro-sizes, with isotropic, anisotropic, homogeneous or heterogeneous properties, which are either difficult or very costly to produce by conventional methods [12]. The interest on porous bio-replicas based on metal oxides such as $\mathrm{Al}_{2} \mathrm{O}_{3}, \mathrm{TiO}_{2}$ and $\mathrm{ZrO}_{2}$ has been increasing in the last decades for their interest in photocatalysis and photovoltaic, specially for manufacturing of gas sensors, filters, catalysts carriers, etc. $[13,14]$. Lignocellulosic masks stand out among the wide range of materials suitable to be used as templates $[15,16]$, due to their ecological and economical origin, obtained from renewable and even residual resources, which make it interesting as valorization process $[17,18]$.

The textural and crystallographic stability of aluminas are of great importance for processes involving high temperatures, such as regeneration of catalyst beds and membranes, being the collapse of alumina structure a limiting factor of the process efficiency. High temperatures and high residence times reduce the specific surface area of alumina due to the 
transformation to alpha phase, which is accompanied by coalescence and sintering phenomena. Thus, the attainment of thermally stable alumina keeping high specific surfaces areas is the goal of many researches. Ordered mesoporous aluminas exhibit $\mathrm{S}_{\mathrm{BET}}$ values ranging between 200 and $500 \mathrm{~m}^{2} / \mathrm{g}$ after calcination at temperatures between 450 and $700{ }^{\circ} \mathrm{C}[1]$, and exceptionally 700 $800 \mathrm{~m}^{2} / \mathrm{g}[19,20]$. The surface area diminishes considerably at temperatures as high as $1000^{\circ} \mathrm{C}$. It was described the cationic surfactant synthesis of $\gamma-\mathrm{Al}_{2} \mathrm{O}_{3}$ with a resulting surface of $130 \mathrm{~m}^{2} / \mathrm{g}$ after a thermal treatment at $1000{ }^{\circ} \mathrm{C}$ for $2 \mathrm{~h} \mathrm{[21].} \mathrm{At} \mathrm{the} \mathrm{same} \mathrm{calcination} \mathrm{temperature,} \mathrm{a} \mathrm{mixture}$ of $(\gamma+\delta)-\mathrm{Al}_{2} \mathrm{O}_{3}$ with $90 \mathrm{~m}^{2} / \mathrm{g}$ was obtained by nanocasting [22]. Recently, it was reported the generation of gamma-alumina monoliths through gel-casting of mesoporous alumina powder and polymerization additives, reaching $110 \mathrm{~m}^{2} / \mathrm{g}$ after calcination at $1000{ }^{\circ} \mathrm{C}$ for $10 \mathrm{~h}$ [23].

Different works have dealt with the synthesis of porous alumina employing cellulose derived templates. The results obtained up to the moment consist of sintered alpha alumina cellular ceramics [24-26] and mesoporous aluminas which, as the ones obtained by conventional synthetic methods, do not maintain elevated specific surface area at high temperatures. Using filter paper as cellulose support, Shigapov et al. [27] synthesized alumina with $322 \mathrm{~m}^{2} / \mathrm{g}$ after calcination at $800{ }^{\circ} \mathrm{C}$ for $2 \mathrm{~h}$, which decreases to $21 \mathrm{~m}^{2} / \mathrm{g}$ after treatment at $1050{ }^{\circ} \mathrm{C}$ for $12 \mathrm{~h}$. Patel and Padhi [28] obtained at $1000{ }^{\circ} \mathrm{C}$ alumina fibres with $56 \mathrm{~m}^{2} / \mathrm{g}$ by infiltration of jute fibres. Fan et al. [29], through natural cotton fibres, attained $\gamma-\mathrm{Al}_{2} \mathrm{O}_{3}$ with surfaces areas of 127.6 and $125.1 \mathrm{~m}^{2} / \mathrm{g}$ after a calcinations period of $2 \mathrm{~h}$ at 800 and $1000{ }^{\circ} \mathrm{C}$, respectively.

In the present paper, it is described the synthesis of thermally stable alumina fibres of high specific surface area up to $1000{ }^{\circ} \mathrm{C}$, which reproduce the morphology of sisal fibres. In a first part, changes experimented by the lignocellulosic template after their infiltration with the inorganic precursor are presented, as well as thermal phenomena occurring during transformation to alumina during pyrolysis and calcinations stages. In a second part, the composition, morphology and structure of the resulting alumina ceramic fibres are characterized. 


\section{Experimental section}

\subsection{Synthesis}

Natural sisal fibres used in this work, named NS, were provided by Cayetano García del Moral S. L. (Cabra de Santo Cristo, Jaén, Spain). The fibres, manually cut to 2-4 mm length, were subjected to an alkalinization processes to conditioning the surface of the fibres before the infiltration stage. The alkali treatment was performed for $2 \mathrm{~h}$ at room temperature with a $4 \%$ $\mathrm{NaOH}$ solution (Panreac, 231686), followed by exhaustive washing with distilled water. Acetic acid drops were added in the penultimate washing step. Pretreated sisal fibres are designated as PS.

An aqueous solution of aluminium trichloride was prepared using $\mathrm{AlCl}_{3} \cdot 6 \mathrm{H}_{2} \mathrm{O}($ Panreac, 141097), $\mathrm{HCl}$ (37\% Panreac, 131020) and aluminium foil, with the following molar ratio 1.5:1:0.75. PS fibres were immersed in the precursor solution for $240 \mathrm{~h}$, washed with absolute EtOH (Panreac, 141086) and allowed to dry at ambient temperature. Dry infiltrated sisal fibres, named IS, were thermally treated in tubular furnace (Thermolyne F59340CM). The process consisted of a pyrolysis/carbonization stage under nitrogen for $1 \mathrm{~h}$, immediately followed by an oxidation stage under air for $15 \mathrm{~h}$ at $1000{ }^{\circ} \mathrm{C}$. An additional heating cycle was conducted at $1000{ }^{\circ} \mathrm{C}$ for $4 \mathrm{~h}$ using moistured air saturated at room temperature. In order to test its thermal stability, another sample was prepared under the same conditions but which is also subjected to an additional heating cycle at $1000{ }^{\circ} \mathrm{C}$ for $4 \mathrm{~h}$ using humid air, water saturated at room temperature. The resulting ceramic fibres are referred as AF and AFh respectively.

\subsection{Characterization methods}

SEM analyses were performed on JSM-6400 and SM-6490LV JEOL microscopes. The latter is coupled to an Oxford Instruments INCAx-Sight EDAX system, used to analyze infiltrated fibres.

ATR-FTIR spectra were collected, on a Bruker Vertex 77 spectrometer and a Specac Golden Gate ATR accessory, after 32 scans for the range $4000-500 \mathrm{~cm}^{-1}$, with a resolution of 4 $\mathrm{cm}^{-1}$. 
XRD measurements were conducted in a Philips X'Pert PRO MPD, with a X'Celerator RTMS system, using $\mathrm{Cu} \mathrm{K}_{\alpha 1}(\lambda=1.5406 \AA)$ monochromatic radiation. The proportion of ordered regions of cellulose fibrils was determined for alkalized and infiltrated fibres using the crystallinity index $(C I)$, calculated by Segal equation [30]:

$\% C I=\left(1-\left(I_{a m} / I_{\max }\right)\right) \cdot 100$

where $I_{\max }$ is the intensity of the main lattice reflection of cellulose, corresponding to the (002) plane located around $22^{\circ}(2 \theta)$, and $I_{a m}$ is the intensity attributed to amorphous material, around $18^{\circ}$, for $\mathrm{I}_{\beta}$ type cellulose. Alumina crystallite size was estimated through the Scherrer equation applied to (440) and (113) planes for $\gamma-\mathrm{Al}_{2} \mathrm{O}_{3}$ and $\alpha-\mathrm{Al}_{2} \mathrm{O}_{3}$ respectively.

The crystallographic evolution of two portions of infiltrated fibres was followed dynamically by temperature programmed X-ray diffraction (TXRD), scanning each diffractogram every $50{ }^{\circ} \mathrm{C}$ for $40 \mathrm{~min}$. A fraction of the sample was heated from room temperature to $400{ }^{\circ} \mathrm{C}$ under inert atmosphere with a rate of $5{ }^{\circ} \mathrm{C} / \mathrm{min}$. Another fraction was prepyrolized at $500{ }^{\circ} \mathrm{C}$ and, after being finely ground, it was heated from 500 to $1150{ }^{\circ} \mathrm{C}$ at 10 ${ }^{\circ} \mathrm{C} / \mathrm{min}$. The analysis was performed under nitrogen atmosphere between 500 and $900{ }^{\circ} \mathrm{C}$ and under oxidizing atmosphere between 950 and $1150^{\circ} \mathrm{C}$.

TG/DSC analyses were carried out in a SDT 2960 TA Instrument, under nitrogen and air atmospheres with a rate of $10^{\circ} \mathrm{C} / \mathrm{min}$. The released gases were analyzed in a Bruker VECTOR 22 infrared spectrometer coupled to the outlet port of the SDT. The transfer line and the cell were kept at $300{ }^{\circ} \mathrm{C}$. Spectra were recorded in the range $4000-500 \mathrm{~cm}^{-1}$ every 61 seconds, after 64 scans and with a resolution of $4 \mathrm{~cm}^{-1}$.

XRF semi-quantitative analyses were performed using energy-dispersive X-ray instruments, Axios PW4400 from PANalytical and XGT-5000WR from Horiba. 
TEM micrographs and SAED electron diffraction patterns were collected on a Philips CM-200 microscope. Previously, alumina sample was dispersed in EtOH, stirred in an ultrasonic bath and, finally, one drop was deposited on carbon-coated copper grid.

XPS analysis of ground alumina sample was performed in a PHI 5700 Physical Electronics spectrometer, employing non-monochromatic Mg Ka radiation (1253.6 eV). The photoemission peaks were calibrated respect to the signal C 1 s for adventitious carbon $(284.8$ $\mathrm{eV})$ prior to the fitting procedure.

Solid state ${ }^{27} \mathrm{Al}$ MAS-NMR analysis was conducted on a Bruker DRX-400 spectrometer, under a magnetic field of $9.6 \mathrm{~T}$ and a pulse of $1.1 \mu \mathrm{s}$. The powdered sample was spun at a rate of $10 \mathrm{kHz}$ and the chemical shifts were referenced to $1 \mathrm{M} \mathrm{AlCl}_{3} \cdot \mathrm{H}_{2} \mathrm{O}$ solution.

$\mathrm{N}_{2}$ and $\mathrm{CO}_{2}$ adsorption-desorption isotherms were measured with a Micromeritics ASAP 2020 instrument, at $77 \mathrm{~K}\left(-196{ }^{\circ} \mathrm{C}\right)$ and $273 \mathrm{~K}\left(0^{\circ} \mathrm{C}\right)$ respectively. Samples were first degassed at $90{ }^{\circ} \mathrm{C}$ for $1 \mathrm{~h}$ and then at $150{ }^{\circ} \mathrm{C}$ for $8 \mathrm{~h}$ under vacuum. The total surface areas $\left(S_{B E T}\right)$ were determined using the BET equation [31]. The total pore volumes $(V s p)$ were calculated from the amount adsorbed at a $P / P_{0}$ value of 0.995 . The average pore sizes $\left(w_{p}\right)$ were determined approximating the pore geometry to a cylinder. The external surface areas $\left(S t_{e x t}\right)$, micropore areas $\left(S t_{\text {micro }}\right)$ and micropore volumes $\left(V t_{\text {micro }}\right)$ were estimated from t-plot method [32] Mesopore distributions were determined applying the BJH method to the adsorption branch of the isotherms [33]. The thickness t-equation employed is the one proposed by Harkins and Jura $[34,35]$. The surface areas and volumes of narrow-neck micropores, $S_{D R}$ and $V_{D R}$, were estimated from the $\mathrm{CO}_{2}$ adsorption data using the DR equation [36].

\section{Results and discussion}

\subsection{Pretreated and infiltrated sisal fibres}

Micrographs of natural sisal fibres NS, pretreated PS and infiltrated IS are shown in Fig. 1. Typical remnants of the spongy parenchyma cells (Fig. 1a) and the hollow polygonal cells or ultimate cells [37] (Fig. 1b), which constitute a bundle of longitudinal fibres, are visible in the external surface and section of sisal fibre, respectively. The alkalization process is widely used 
for conditioning the surface of the fibres. It cleans the walls by removing waxes and other lipophilic components, and also extracts a fraction of hemicellulose and inorganic constituents. After removing a part of the cementitious matrix, the defibration of longitudinal beam occurs, as can be seen in PS fibres (Fig. 1c), increasing the outer surface. Alkali treatment also produces a more hydrophilic surface due to the more exposed hydroxyl groups from cellulosic components, which could facilitate the subsequent interaction and adsorption of the aqueous solution precursor. The acidic media of the precursor solution generates morphological changes in the surface of sisal fibre after the infiltration step. Thus, IS fibres show a broken and unpaged surface, in which conductive vessels are visible (Fig. 1d).
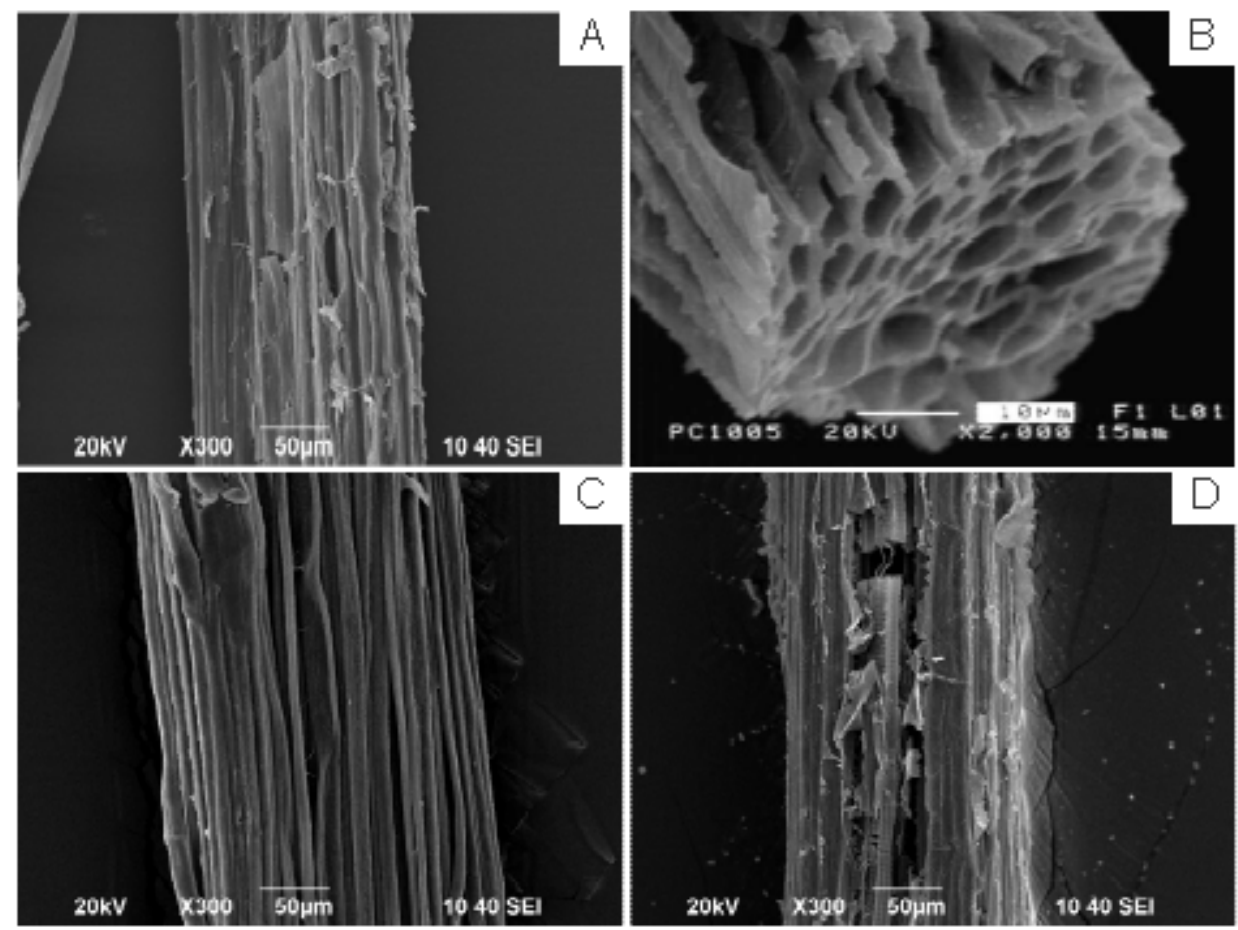

Figure 1: SEM micrographs of natural sisal fibre NS (A), sisal cross-section (B), alkalized sisal fibre PS (C), infiltrated sisal IS (D).

Like any plant, sisal absorbs nutrients and different soil minerals, essential for its growing, and which turn into constituents of sisal fibres, in addition to cellulose, hemicellulose, lignin and other smaller carbohydrates. Table 1S presents the composition of the ashes of NS and PS. Calcium is the most abundant element in sisal, being mainly found as hydrated calcium 
oxalate secretions, which decreases after washing and alkali treatments, increasing consequently the proportion of $\mathrm{Na}$ and $\mathrm{Mg}$.

Table 1S. XRF compositional analysis of natural NS and alkalized PS sisal ashes, and AFh alumina sample.

\begin{tabular}{|l|c|c|c|c|}
\hline \% ash & NS & PS & & AFh \\
\hline \%weight & 0.67 & 0.71 & & \\
$\mathrm{Ca}$ & 74.39 & 58.68 & \%weight $^{2} \mathrm{Al}_{2} \mathrm{O}_{3}$ & 99.36 \\
$\mathrm{Mg}$ & 10.22 & 29.74 & $\mathrm{Ca}$ & 0.28 \\
$\mathrm{Si}$ & 3.60 & 2.63 & $\mathrm{Fe}$ & 0.27 \\
$\mathrm{Na}$ & 3.54 & 4.96 & $\mathrm{Mn}$ & 0.09 \\
$\mathrm{Fe}$ & 2.32 & 1.09 & & \\
$\mathrm{~S}$ & 1.94 & 1.16 & & \\
$\mathrm{~K}$ & 1.16 & 0.11 & & \\
$\mathrm{Al}$ & 1.14 & 0.48 & & \\
$\mathrm{P}$ & 0.65 & 0.06 & & \\
$\mathrm{Sr}$ & 0.42 & 0.14 & & \\
$\mathrm{Ti}$ & 0.17 & & & \\
$\mathrm{Mn}$ & 0.16 & 0.20 & & \\
$\mathrm{Cu}$ & 0.10 & 0.56 & & \\
$\mathrm{Ba}$ & 0.09 & & & \\
$\mathrm{Zn}$ & 0.05 & 0.13 & & \\
$\mathrm{Cl}$ & 0.05 & 0.06 & & \\
\hline
\end{tabular}

After infiltration, sisal fibres are covered with an amorphous compound derived from aluminium chloride. The EDX analyses done on different areas of IS fibre (Fig. 2) are shown in

\section{Table 1.}

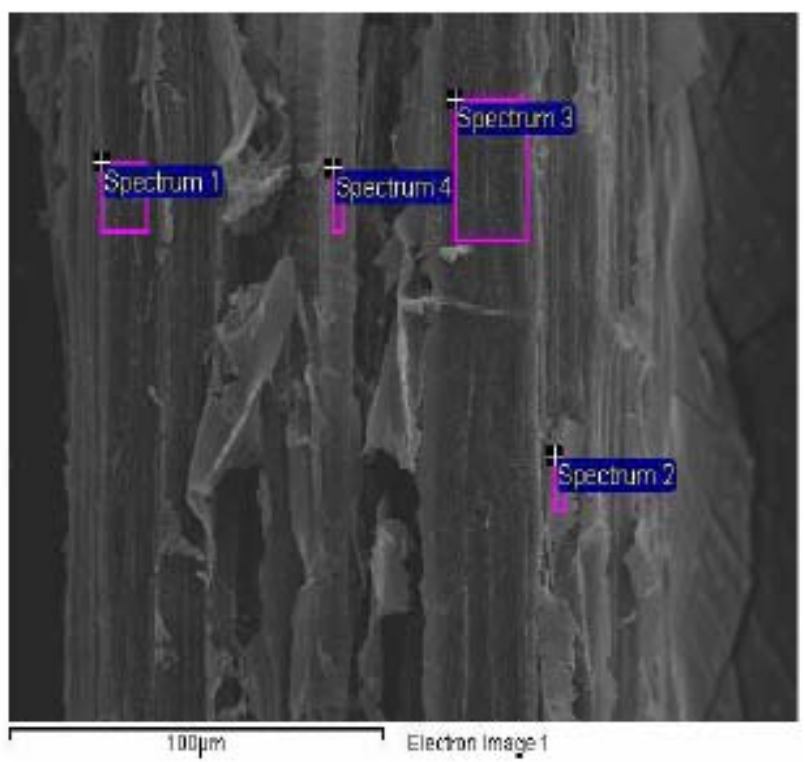

Figure 2: Selected regions on infiltrated fibres for EDX analysis. 
Table 1. EDX chemical analysis of the infiltrated sisal fiber, IS, shown in Fig. 2

\begin{tabular}{|r|c|c|c|c|}
\hline \% weight & Spectrum 1 & Spectrum 2 & Spectrum 3 & Spectrum 4 \\
\hline $\mathrm{C}$ & 48.60 & 48.22 & 60.38 & 46.50 \\
$\mathrm{O}$ & 45.34 & 44.89 & 33.04 & 43.64 \\
$\mathrm{Na}$ & & & 0.66 & 0.36 \\
$\mathrm{Mg}$ & & 0.13 & & 0.23 \\
$\mathrm{Al}$ & 2.41 & 4.22 & 2.18 & 4.28 \\
$\mathrm{Si}$ & & & & 0.56 \\
$\mathrm{Cl}$ & 3.15 & 2.46 & 3.61 & 4.17 \\
$\mathrm{~K}$ & & 0.08 & & 0.17 \\
$\mathrm{Ca}$ & & & & 0.14 \\
$\mathrm{Mn}$ & 0.13 & & & \\
$\mathrm{Fe}$ & 0.04 & & & \\
\hline
\end{tabular}

A compositional heterogeneity can be observed, which would be indicative of a different local reactivity towards the aluminium precursor. Thus, some regions show $\mathrm{Al} / \mathrm{Cl}$ ratios closed to those of dimeric and trimeric aluminium complexes, while other regions show $\mathrm{Al} / \mathrm{Cl}$ ratios closed to that of the polymer.

Moreover, infiltration modifies the lignocellulosic structure, as can be proved by XRD and ATR-FTIR analysis. Therefore, the lowest intensity about $2 \theta$ at $18^{\circ}$ observed in the XRD diffractogram for the IS fibres (Fig. 1S) corresponds to a decrease in the amorphous content of sisal fibres, yielding a moderate increase of $\% C I$, as estimated by Eq. 1, up to $\approx 79 \%$ for IS fibre, while that of PS fibre was $\approx 76 \%$.

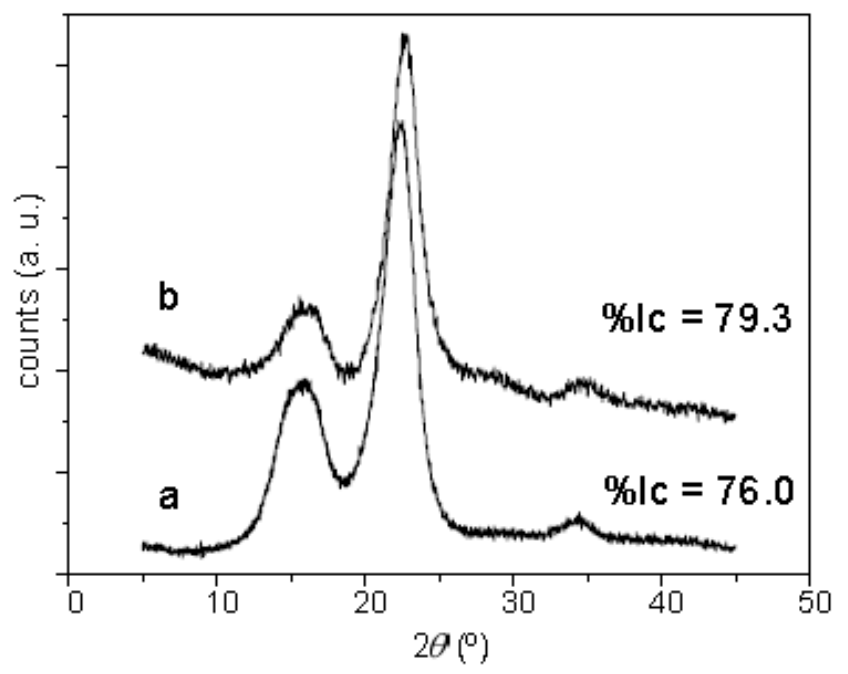

Figure 1S: XRD diffractograms of alkalized PS (a) and infiltrated IS (b) sisal fibers. 
ATR-FTIR spectra of PS and IS fibres are shown in Fig. 3. Primarily, the hemicellulosic components of the cell walls are extracted during alkalization process [38]. The pretreatment performed in the present work is not strong enough to eliminate hemicellulose completely and a small fraction remains, as the presence of a weak band at around $1726 \mathrm{~cm}^{-1}$ (Fig. 3a), associated with the $\mathrm{C}=\mathrm{O}$ stretching of acetyl and acid groups of the hemicellulose side chains reveals. The occurrence of hemicellulose is also corroborated by the TG-DSC analysis, discussed in section 3.2 .

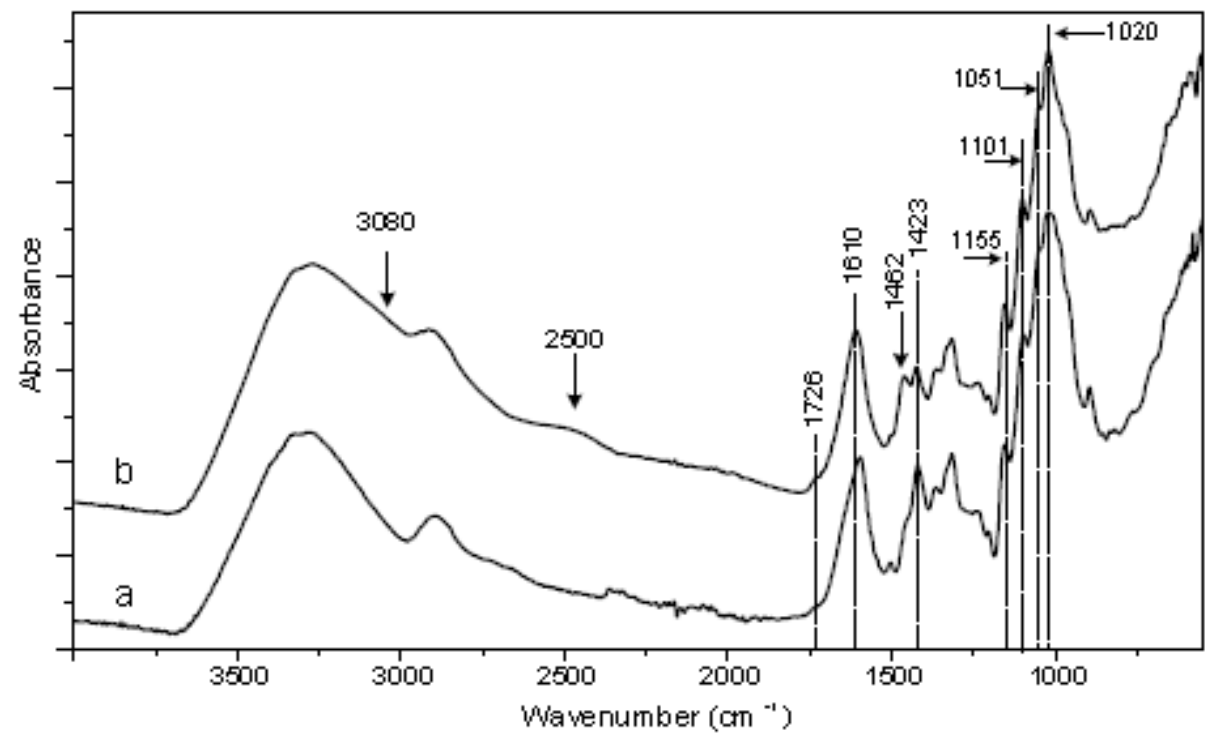

Figure 3: ATR-FTIR spectra of alkalized PS (a) and infiltrated IS (b) sisal fibres.

Infiltration generates several changes in IS fibre visible in the region $4000-800 \mathrm{~cm}^{-1}$ (Fig. 3b), which can be subdivided into:

i) Modifications attributed to the presence of hydrolysed aluminium species that interact with the lignocellulosic fibre.

The hydration environment of these species would be the cause of the most significant changes. Is the case of the new contribution around $3080 \mathrm{~cm}^{-1}$, which produces the broadening of the $\mathrm{OH}$ stretching band. Furthermore, as a consequence of the infiltration, a band of low intensity appears around $2500 \mathrm{~cm}^{-1}$,=associated with $\mathrm{OH}$ stretching mode of $\mathrm{Al}-\mathrm{OH}_{2}$ groups [39] 
and short hydrogen bonds [40]. This suggests that the interaction between precursor and fibre could occur between the hydroxyl groups of hemi/cellulosic components and the hydrolysed aluminium species. Another effect observed is a slight displacement of the band associated to OH deformation mode, from 1597 to $1610 \mathrm{~cm}^{-1}$. The appearance of a new band at around 1462 $\mathrm{cm}^{-1}$ may be associated with the interaction or coordination between aluminium cations and carboxyl groups from components of lignocellulosic fibre, such as glucuronic acids of the remaining hemicellulose side chains. It has been reported that the symmetrical $\mathrm{COO}^{-}$stretching vibration corresponding to the carboxylate bridges established with aluminium centers of different nature are located between $1470-1460 \mathrm{~cm}^{-1}[41,42]$. The corresponding antisymmetric stretching vibrations, located at wavenumbers over1550 $\mathrm{cm}^{-1}$, could contribute to the displacement of the $\mathrm{OH}$-deformation observed.

ii) Changes due to the extraction of components, as well as to the decomposition of carbohydrates during the infiltration period in acid medium.

The decrease in the intensity of asymmetric $\mathrm{CH}$ deformation band situated around 1423 $\mathrm{cm}^{-1}$ is attributed to the extraction of carbohydrates. In the case of lignin this band is mainly related to the $\mathrm{CH}$ deformation vibrations associated to aromatic skeleton, such as methoxyl ($\left.\mathrm{OCH}_{3}\right)$ or hydroxymethyl $\left(-\mathrm{CH}_{2} \mathrm{OH}\right)$ groups $[43,44]$. Also, the decrease of the area of the strong band at $1020 \mathrm{~cm}^{-1}$ is associated to a partial hydrolysis of the polysaccharide chains, as the remanent hemicellulose and cellulose, particularly of "amorphous" character which is chemically more reactive than crystalline cellulose fibrils. It is known that a mild acidic environment and the presence of inorganic salts such as aluminium trichloride, promote this hydrolysis $[45,46]$. This extraction would increase the content of cellulose with a greater structural order, which explains the increased intensity of the characteristic vibrations of cellulose, at 1155,1101 and $1051 \mathrm{~cm}^{-1}$, further corroborated by the higher crystallinity index of the infiltrated fibre IS, as reported above.

Furthermore, alkenes, cycloalkanes and aromatic compounds could be generated as a consequence of the decomposition of carbohydrates in the lignocellulosic fibre, whose $\mathrm{CH}$ 
stretching vibrations around $3100-3010 \mathrm{~cm}^{-1}$, aromatic skeleton and $\mathrm{C}=\mathrm{C}$ stretching modes in the range $1690-1500 \mathrm{~cm}^{-1}$, and $\mathrm{CH}$ deformation vibrations in the range $1470-1430 \mathrm{~cm}^{-1}$, could contribute to the new bands observed in these regions.

\subsection{Thermal evolution of the infiltrated sisal fibres}

The infiltration with the alumina precursor generates changes in the thermal decomposition behaviour of sisal fibre, as it is revealed by TG/DTG-DSC thermograms of alkalized fibres and infiltrated fibres shown in Fig. 4.
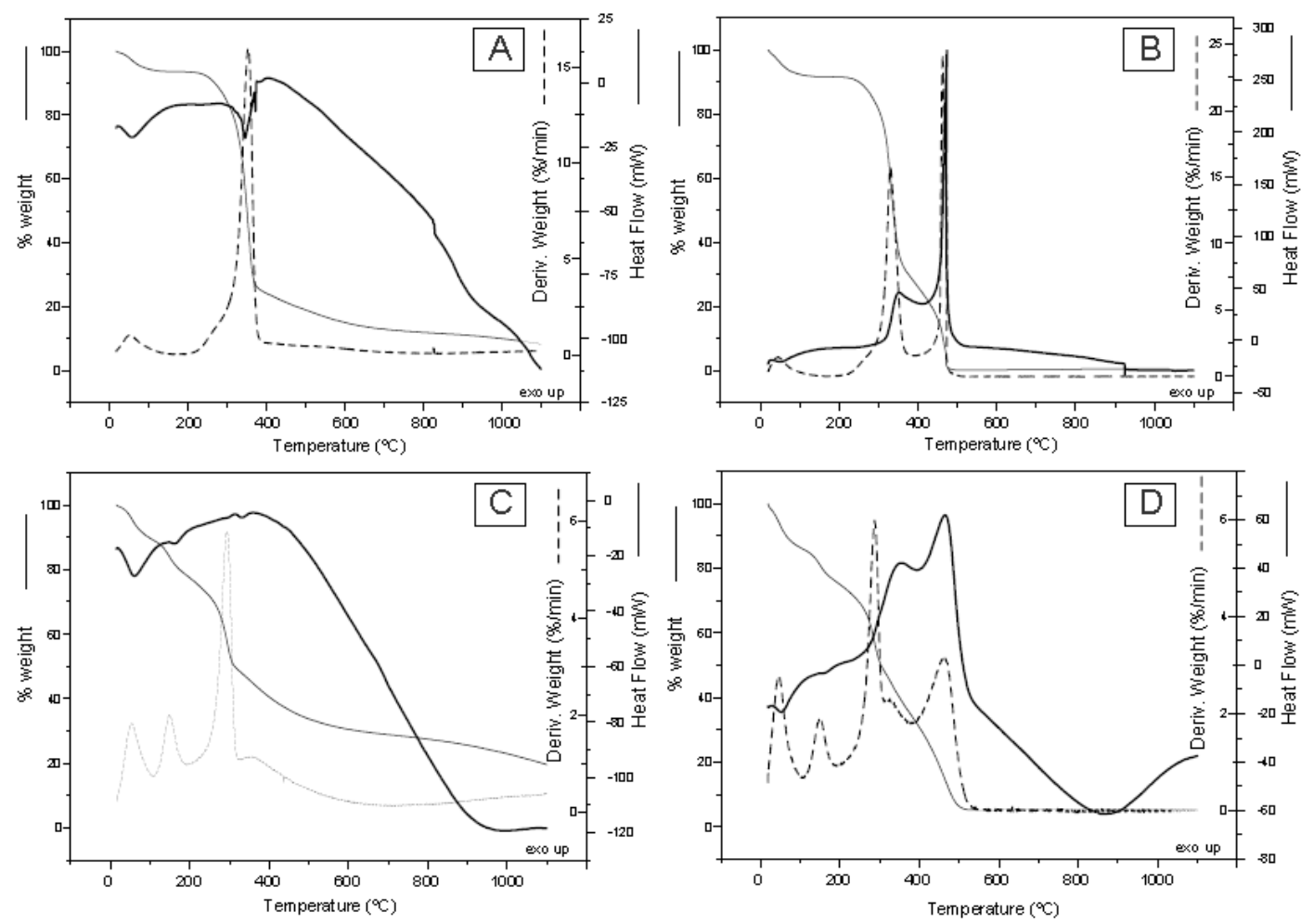

Figure 4: TG/DTG/DSC thermograms of alkalized sisal fibres PS, under nitrogen (A) and air atmospheres (B); the corresponding thermograms for infiltrated fibres IS, under nitrogen (C) and air (D).

While, fundamentally both in nitrogen or air, only three stages are observed for PS (Fig. 4a and Fig. 4b), five stages can be distinguished for the IS (Fig. 4c and Fig. 4d). For both samples, at temperatures below $110{ }^{\circ} \mathrm{C}$, a small weight loss in the $\mathrm{TG}$ signals and a corresponding endothermic effect in the DSC curves are associated with moisture evaporation. Specifically, for PS fibres a second stage is distinguished between 190 and $390{ }^{\circ} \mathrm{C}$, with a total 
mass loss of about $70 \%$ respect to the dry fibre (\% dry basis, d.b.) which corresponds to the overlapping decomposition/pyrolysis of the remaining hemicellulosic components and to cellulose decomposition in a greater proportion $[47,48]$. In this temperature range, the DSC curve under inert atmosphere shows an endothermic effect centred at $347{ }^{\circ} \mathrm{C}$, associated with the heat required to break the glycosidic bonds of cellulose chains, whereas under oxidizing atmosphere it shows an overall exothermic effect around $349^{\circ} \mathrm{C}$, due to the oxidation of volatile compounds. The third step above $400^{\circ} \mathrm{C}$ under inert atmosphere corresponds to the reorganization, condensation and aromatization of the carbon skeleton, accompanied by a small and slow mass loss process. While under air, it corresponds to the combustion of the carbonaceous residue, accompanied by an intense exothermic effect at $475{ }^{\circ} \mathrm{C}$ with a mass loss of $30 \%$ (d.b.).

The simultaneous TG-FTIR analysis of the released gas, shown in Fig. 5, help to clarify the phenomena taking place during the thermal decomposition of IS fibres.

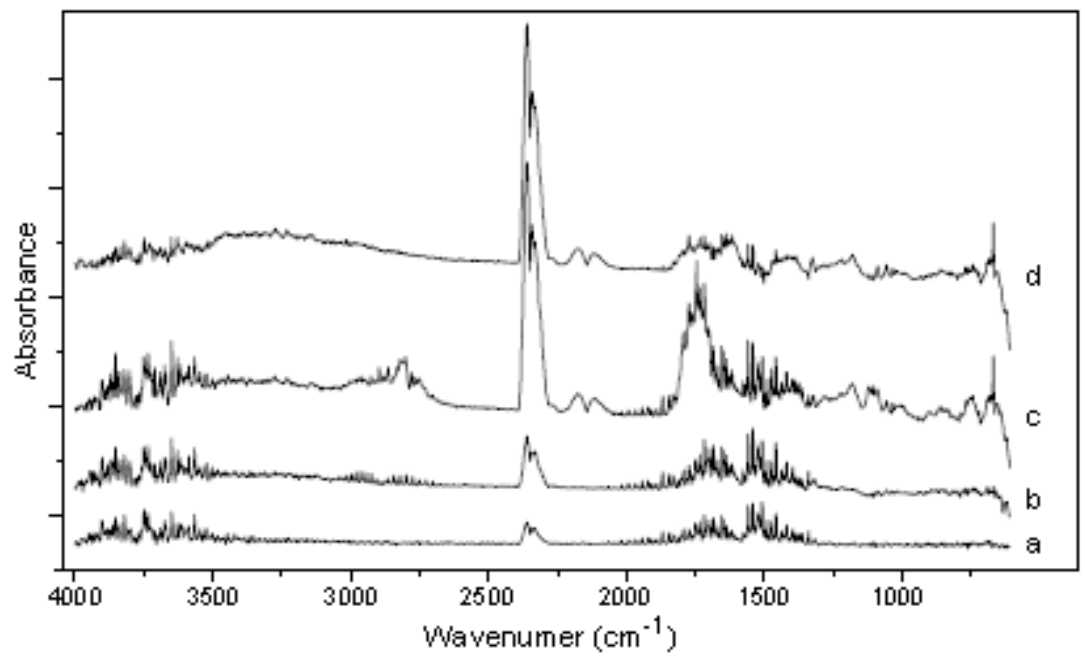

Figure 5: FTIR of gases evolved during decomposition of IS fibres under nitrogen atmosphere, at 52 (a), 150 (b), 293 (d) and $356{ }^{\circ} \mathrm{C}(\mathrm{d})$.

Thus, the first stage below $110{ }^{\circ} \mathrm{C}$ of endothermic character is primarily due to the evolution of $\mathrm{H}_{2} \mathrm{O}$ and $\mathrm{CO}_{2}$, as shows the FTIR spectrum in Fig. 5a, associated with moisture desorption and probably with the early decomposition of labile organic compounds generated 
due to the infiltration. For the second stage, between 110 and $190{ }^{\circ} \mathrm{C}$ is an endothermic process with a mass loss of $12 \%$ (d.b), mainly due to $\mathrm{H}_{2} \mathrm{O}, \mathrm{CO}_{2}$, and in less proportion $\mathrm{HCl}$ (Fig. $5 \mathbf{b}$ ), associated with the alumina precursor dehydration which leads to the release of chloride anions. The third stage, between 190 and $320{ }^{\circ} \mathrm{C}$, presents a mass loss between 32 and $33 \%$ (d.b.) coincident with the release of $\mathrm{CO}_{2}, \mathrm{CO}, \mathrm{H}_{2} \mathrm{O}$, formic acid, methanol, and formaldehyde (Fig. 5c), gases from the pyrolysis of lignocellulosic biomass. Immediately after, it can be distinguished the fourth stage by a lower mass loss, around $16 \%$ in air and $23 \%$ under nitrogen, which is coincident with the maximum temperature rate of decomposition of cellulose observed in PS fibres. Under inert atmosphere, the third and fourth stages occur through a series of exo and endothermic processes whose energies are nearly compensated. However, an exothermic effect around $355^{\circ} \mathrm{C}$ is clearly detected during the thermal decomposition of IS fibres in air, which also occurs for PS fibres, associated with the oxidation of volatiles from cellulose pyrolysis. The fifth stage in nitrogen corresponds to the carbonization process $\left(>400{ }^{\circ} \mathrm{C}\right)$ while in air to the char combustion $\left(>380^{\circ} \mathrm{C}\right)$, an exothermic process with maximum at $465^{\circ} \mathrm{C}$ and a mass loss of $34 \%$ (d.b.).

Infiltration with acidic precursor solutions explains that pyrolysis of lignocellulosic materials takes place through two different processes. Diverse studies have shown that the impregnation of biomass with chemical species such as $\mathrm{AlCl}_{3}, \mathrm{H}_{3} \mathrm{PO}_{4}, \mathrm{H}_{2} \mathrm{SO}_{4}, \mathrm{HCl}, \mathrm{FeCl}_{3}$, $\mathrm{ZnCl}_{2} \mathrm{NH}_{4} \mathrm{Cl}$ promotes dehydration and inhibits depolymerization of cellulose [49,50]. Thus, for IS sample, the intense third stage around $290^{\circ} \mathrm{C}$ can be associated with the decomposition of cellulose through a dehydration mechanism, leading to the formation of char, while the less intense fourth stage around $350{ }^{\circ} \mathrm{C}$ can be assigned to the cellulose depolymerization process, observed in PS fibres, which mainly generates volatile products. The global energy balance would be the result of exothermic carbonization and endothermic volatilization processes $[51,52]$.

\subsection{Correlation between decompositon of biotemplate and crystallization of alumina}


The formation of alumina phase is influenced by the decomposition of sisal fibre biotemplate, as deduced from the structural evolution of the alumina precursor analyzed by TDRX. At low temperatures the crystallization of aluminium hydroxides or oxyhydroxides is not perceptible. From room temperature until $250{ }^{\circ} \mathrm{C}$, only the reflections from cellulose are observed in the range from 15 to $22^{\circ}$ (Fig. 6.1). With increasing temperature, cellulose loses its crystalline structure progressively, thus decreasing the crystallinity index (Fig. 6.2), being completely amorphous from $250{ }^{\circ} \mathrm{C}$, which is coincident with the main decomposition step of IS fibre (third stage).
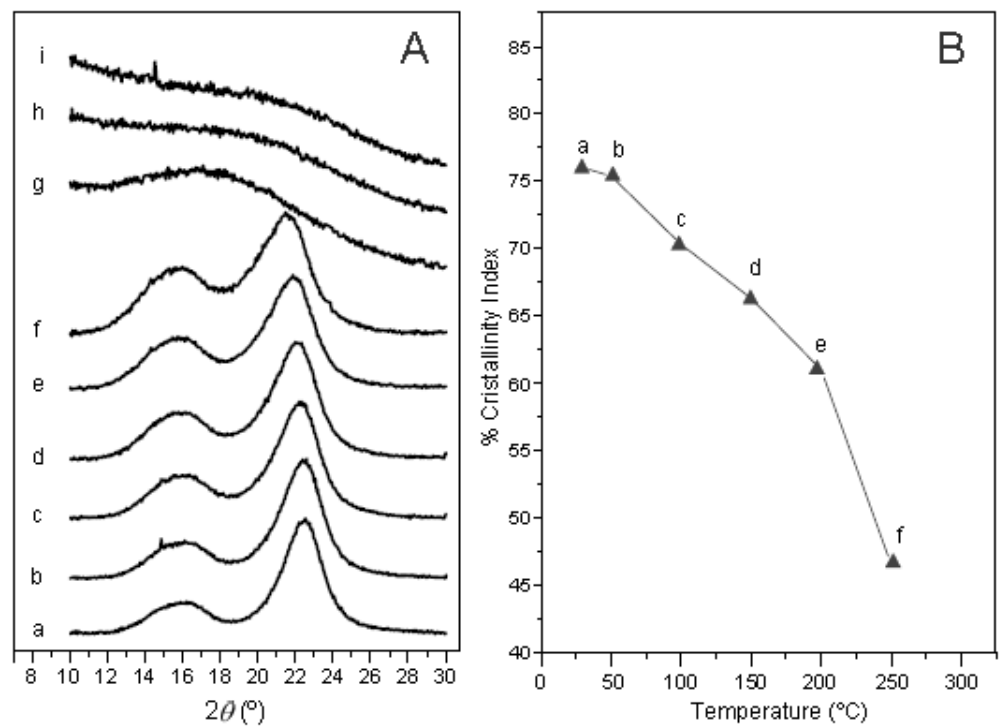

Figure 6: TXRD under inert atmosphere of IS fibres (A), at 30 (a), 50 (b), 100 (c), 150 (d), 200 (e), 250 (f), 300 (g), 350 (h) and $400{ }^{\circ} \mathrm{C}$ (i). Evolution of the corresponding crystallinity index (B). 


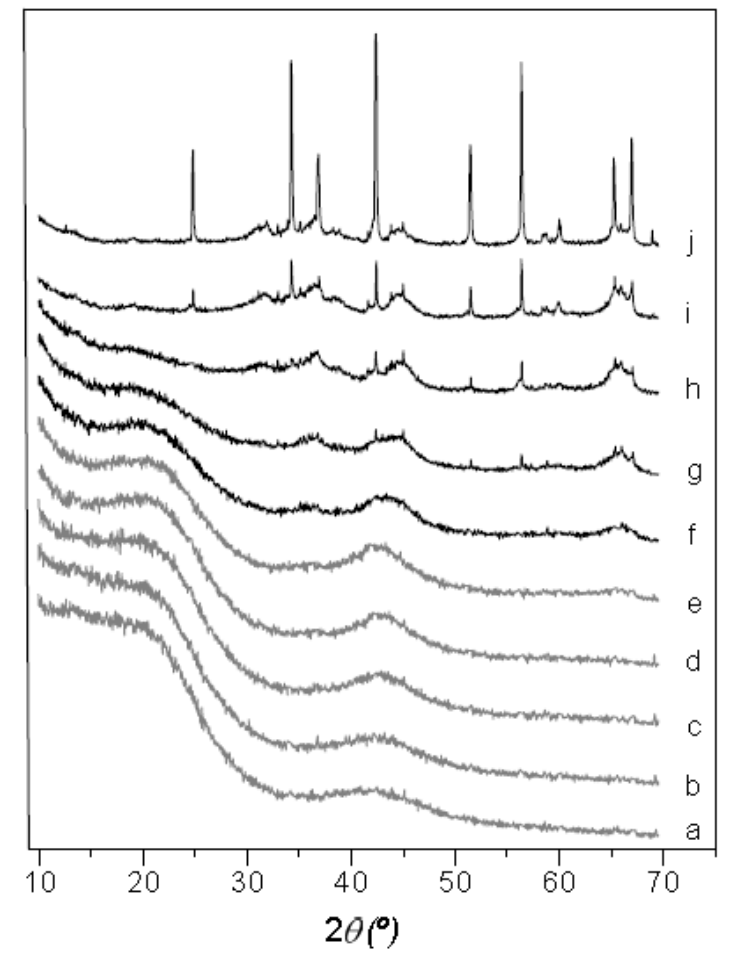

Figure 7: TXRD evolution of IS fibres pre-pyrolized at $500{ }^{\circ} \mathrm{C}$, studied under inert atmosphere (grey lines) at 500 (a), 600 (b), 700 (c), 800 (d) and $900{ }^{\circ} \mathrm{C}(\mathrm{e})$, under air (black lines) at 950 (f) y 1000 (g), 1050 (h), 1100 (i) and $1150^{\circ} \mathrm{C}$ (j). Reflexion peaks at $2 \theta=42.4,51.5,56,65.4$ and $67^{\circ}$ correspond to $\alpha$ $\mathrm{Al}_{2} \mathrm{O}_{3}$.

Under inert atmosphere, as temperature rises above $500{ }^{\circ} \mathrm{C}$ two wide peaks emerge around 21 and $43^{\circ}$, as shown in Fig. 7(a-e), associated with pseudomorphic carbon of the sisal template [25], specifically to (002) and (100) reflections of turbostratic carbon, which appears graphitized at $1200{ }^{\circ} \mathrm{C}$ as shows Fig. 2S. When air is introduced to the system and the combustion of carbonaceous material occurs, aluminium oxide develops rapidly and lowtemperature $\left(\gamma-\mathrm{Al}_{2} \mathrm{O}_{3}\right)$ and high-temperature transition aluminas $\left(\delta-\mathrm{Al}_{2} \mathrm{O}_{3}, \theta-\mathrm{Al}_{2} \mathrm{O}_{3}\right)$ emerge, even $\alpha-\mathrm{Al}_{2} \mathrm{O}_{3}$ is detected at temperatures below $1100^{\circ} \mathrm{C}$, as is shown in Fig. $7(\mathbf{f}-\mathbf{h})$. 


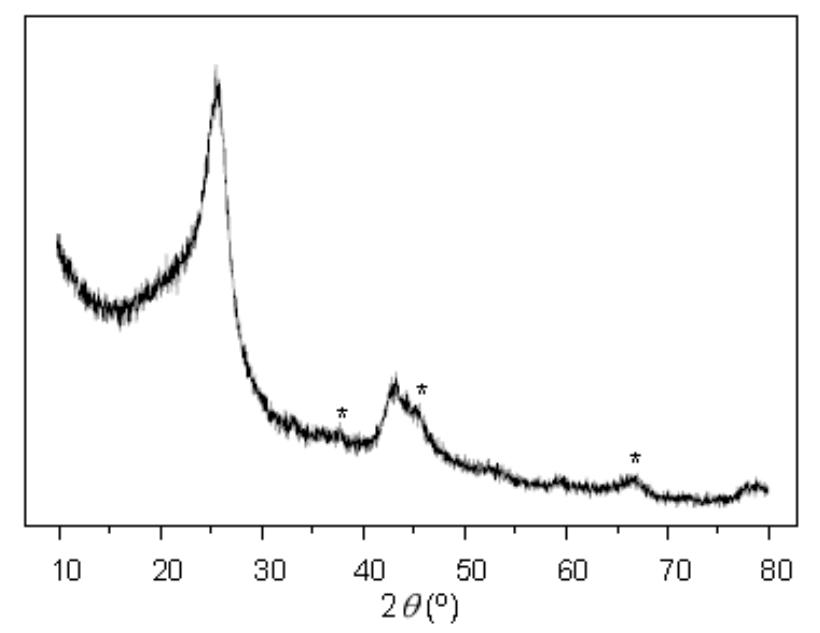

Figure 2S: XRD diffractograms of infiltrated fibers carbonized at $\left.1200{ }^{\circ} \mathrm{C} .{ }^{*}\right)$ Reflexions attributed to $\gamma$ $\mathrm{Al}_{2} \mathrm{O}_{3}$.

The fact that the crystalline phase of alumina corresponding to a given temperature do not develop completely under inert atmosphere, could be attributed to carbonaceous skeleton of the biotemplate, which hinders the nucleation and growth of aluminium oxide from the carbonalumina composite. Only when carbonaceous material is removed by combustion, the alumina crystallites begin to develop freely. Recent studies show that the presence of carbon delays the crystallographic progression of alumina [53]. It follows that the crystallographic development of alumina must be different depending on whether the aluminium oxide is in contact with the carbon network or if is isolated. Further, the mineral matter from the biotemplate and from the precursor solution will influence the growth of crystalline alumina phases.

\subsection{Alumina ceramic fibres}

SEM micrographs of Fig. 8 clearly evidence the structure of the alumina ceramic fibres, which perfectly reproduce the morphology of sisal fibres, where parenchymal cell fragments (Fig. 8a), vascular tissues (Fig. 8b) and bundles of ultimate fibres (Fig. 8c and Fig. 8d) can be observed. 

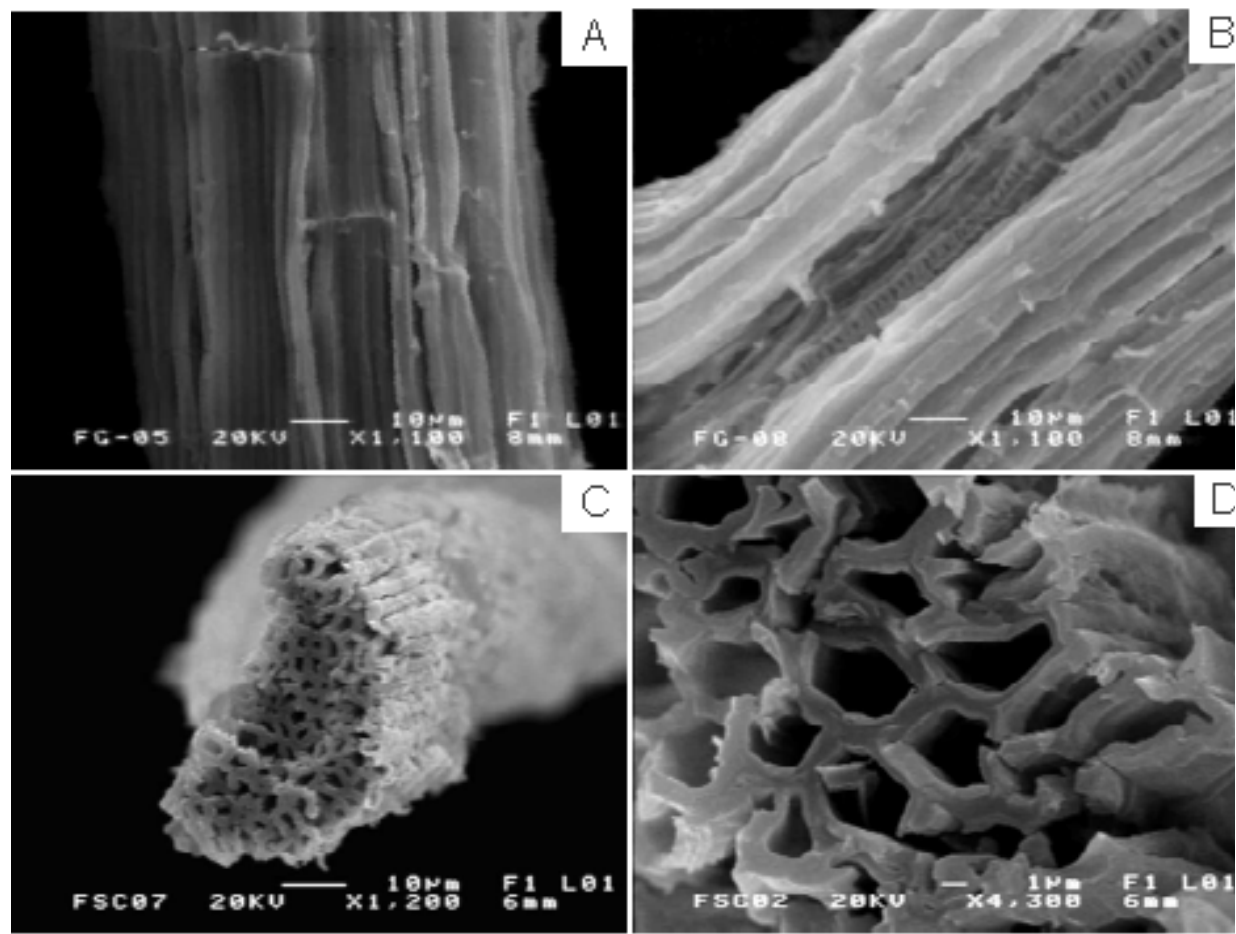

Figure 8: SEM micrographs of alumina fibres. Longitudinal (A, B) and cross-section (C, D) views corresponding to AFh sample.

XRF analysis performed on AFh fibre, given in Table 1S reveals that the method used in the present paper produces alumina fibres with a small content of $\mathrm{Ca}$, from sisal fibre, in addition to small amounts of impurities of $\mathrm{Fe}$ and $\mathrm{Mn}$, from the aluminium alloy foil used as precursor. However, the amount of remaining calcium in sisal fibre after alkalization and infiltration processes is not sufficient to be detected by XRD as crystalline calcium aluminate phases, such as $\mathrm{CaAl}_{12} \mathrm{O}_{19}$, registered by other authors [26]. In any case, these impurities should be considered for the potential applications of the generated alumina fibres.

The main alumina phase in AF and AFh samples, identified by XRD patterns Fig. 9, corresponds to a transition alumina with cubic structure (patterns 10-0425 and 79-1558 PDF files), associated with $\gamma-\mathrm{Al}_{2} \mathrm{O}_{3}$ [54], and a small proportion of $\alpha-\mathrm{Al}_{2} \mathrm{O}_{3}$ crystallites (10-0173 PDF file) larger in the sample AFh. In this case the steam should have a mineralizer effect on the formation of alpha phase $[55,56]$. 


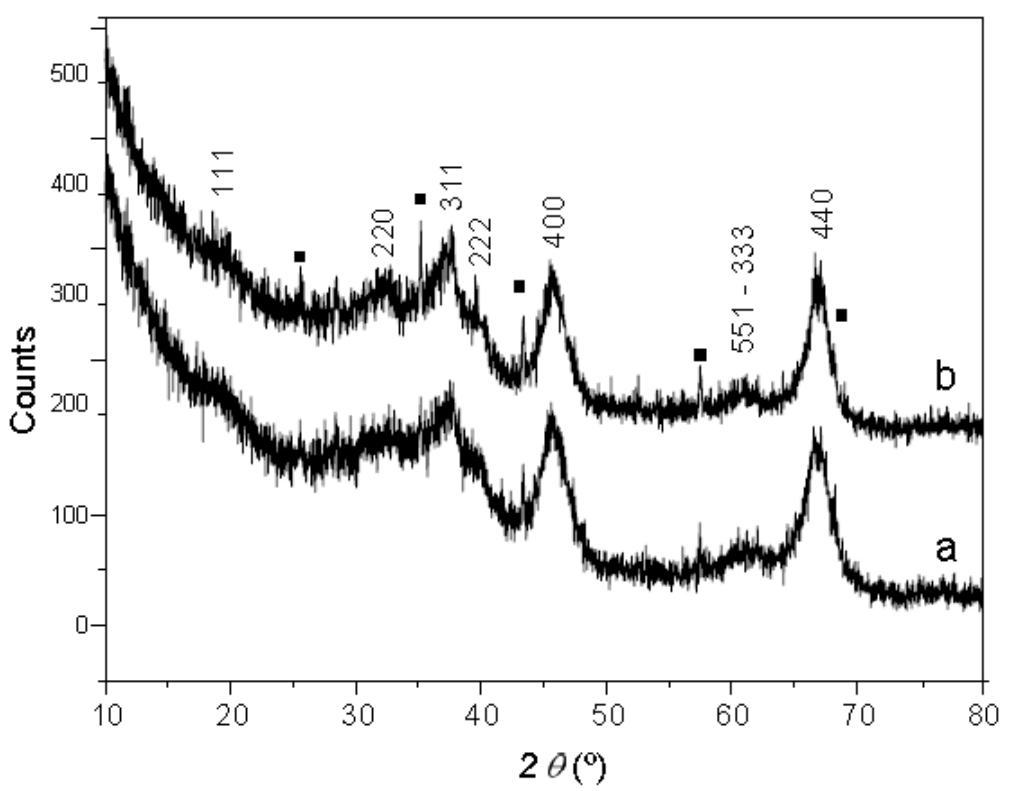

Figure 9: XRD diffractograms of AF (a) and AFh (b) samples. The last is slightly moved along y-axis for better viewing. ( $\mathbf{a}) \alpha-\mathrm{Al}_{2} \mathrm{O}_{3}$.

The existence of gamma and alpha alumina at $1000^{\circ} \mathrm{C}$ can be explained as follows. The presence of transition phases may be related to the small size of aluminium oxide crystalline seeds formed during the carbonization process, due to the inhibitory effect of the carbonaceous scaffold, as commented in section 3.2. Moreover, the relatively low temperature of formation of alpha phase with respect to the typical phase transition scheme proposed by Stumpf et al. [57] and Tertian and Papée [58], could be due to various causes, such as the formation of a gel composed of hydrolyzed polynuclear aluminium species during the infiltration step. It has been described that aluminas generated from polyaluminium species, in particular from basic aluminium chlorides, have lower transition temperatures than usual $[59,60]$. Furthermore, the local temperature increase due to the combustion process of the carbonaceous matrix can help to overcome the energy barrier necessary for the formation of alpha phase $[61,62]$. The distinction between the transition aluminas $\eta-\mathrm{Al}_{2} \mathrm{O}_{3}$ and $\gamma-\mathrm{Al}_{2} \mathrm{O}_{3}$ is complex because they show very similar crystal structures. In principle, the higher definition of the reflection associated to (222) plane and the less intense reflection of the plane (111), at around $4.6 \AA$, suggest that the transition phase corresponds to $\gamma-\mathrm{Al}_{2} \mathrm{O}_{3}$ [63]. The peak widths are indicative of the nano-sized alumina crystallites, estimated at 4.1 and $5.5 \mathrm{~nm}$ for AF and AFh samples respectively. 
ATR-FTIR spectrum of both alumina samples, presented in Fig. 10, does not discard the presence of $\eta-\mathrm{Al}_{2} \mathrm{O}_{3}$. The wavenumbers below $1000 \mathrm{~cm}^{-1}$ are related to the characteristics Al-O vibration of aluminas. The region below $700 \mathrm{~cm}^{-1}$, associated with $\mathrm{Al}-\mathrm{O}$ stretching vibrations of octahedrally coordinated aluminium $\left(v-\mathrm{AlO}_{6}\right)$, is more intense compared to the region $900-750 \mathrm{~cm}^{-1}$, associated with Al-O stretching vibrations of aluminium in tetrahedral coordination $\left(v-\mathrm{AlO}_{4}\right)$, feature shared by low temperature transition aluminas, as $\eta$ and $\gamma-\mathrm{Al}_{2} \mathrm{O}_{3}$ phases [64].

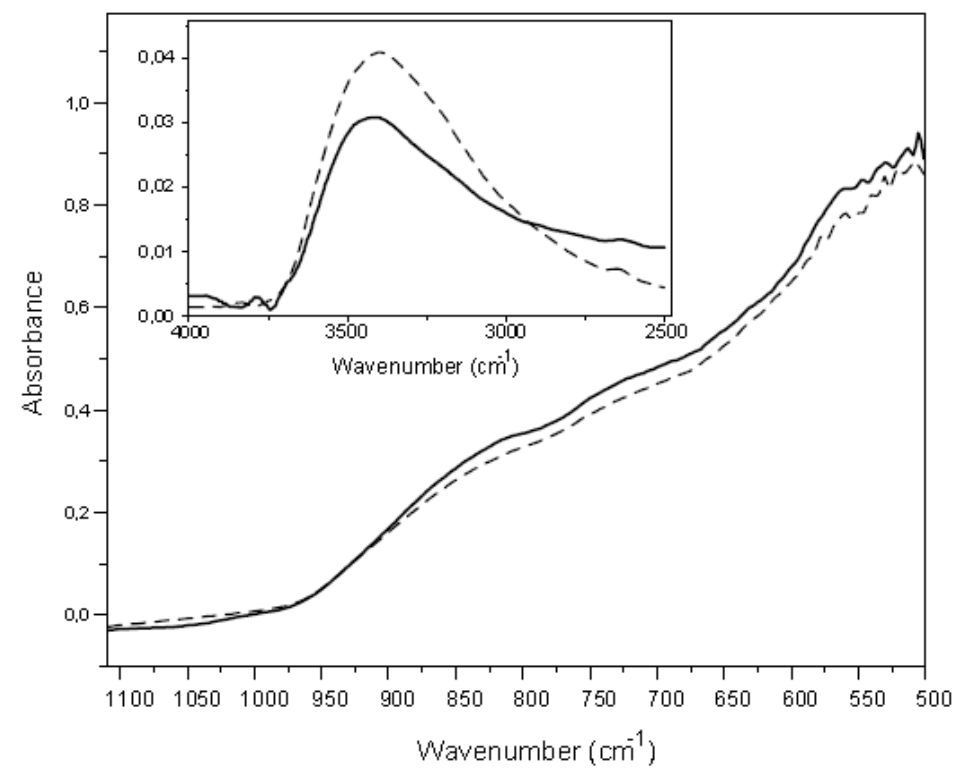

Figure 10: ATR-FTIR spectra of AF (discontinuous line) and AFh (continuous line) samples.

${ }^{27} \mathrm{Al}$ MAS-NMR analysis has been configured as a method for distinguishing the coordination environments of aluminium, allowing to discern different phases of alumina in a complementary manner. In the case of $\eta-\mathrm{Al}_{2} \mathrm{O}_{3}$ and $\gamma-\mathrm{Al}_{2} \mathrm{O}_{3}$ their fractions of octahedrally coordinated aluminium have been quantified about $65 \pm 4 \%$ and $75 \pm 4 \%$ respectively $[65,66]$. Two signals centred at 7 and $64 \mathrm{ppm}$ are observable in the spectrum of AFh fibres shown in Fig. 11, associated respectively with $\mathrm{Al}^{3+}$ in octahedral position $\left(\mathrm{Al}^{\mathrm{VI}}\right)$ and tetrahedral $\left(\mathrm{Al}^{\mathrm{IV}}\right)$, not being perceptible the alpha phase contribution, characterized by an octahedral environment around $13 \mathrm{ppm}$ [40]. It has been estimated that the proportion of $\mathrm{Al}^{\mathrm{VI}}$ is close to $70 \%$, which suggests that both phases remain even after a reheating cycle with humid air. 


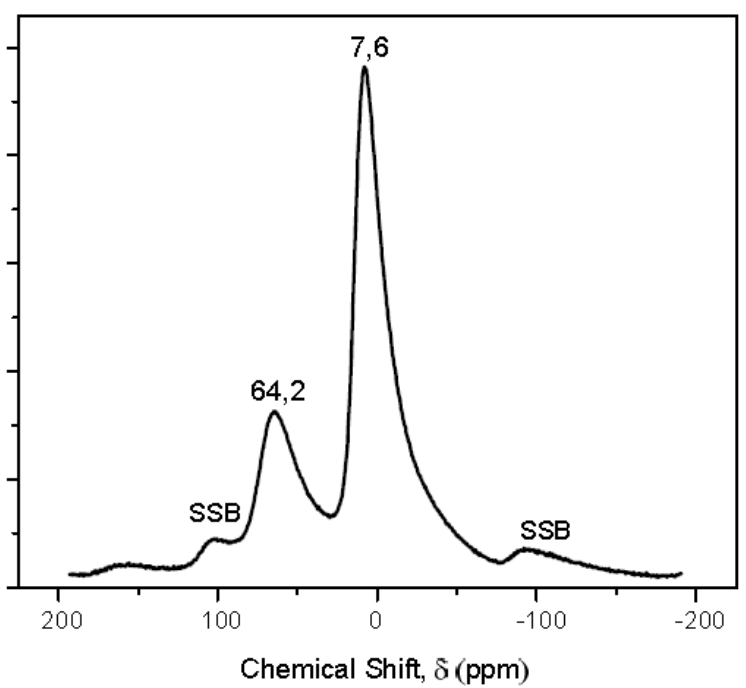

Figure 11: ${ }^{27} \mathrm{Al}-\mathrm{MAS}-\mathrm{RMN}$ of AFh sample (SSB: spinning side bands).

The infrared band centred at $3400 \mathrm{~cm}^{-1}$ and the shoulder around $3200 \mathrm{~cm}^{-1}$, shown in the inset plot of Fig. 10, are associated with O-H stretching modes of hydroxyl groups located at the surface of aluminium oxide, resulted from the moisture adsorption, which can be distinguished by XPS analysis. Survey and multi-region XPS spectra of AFh fibre are shown in Fig. 12.
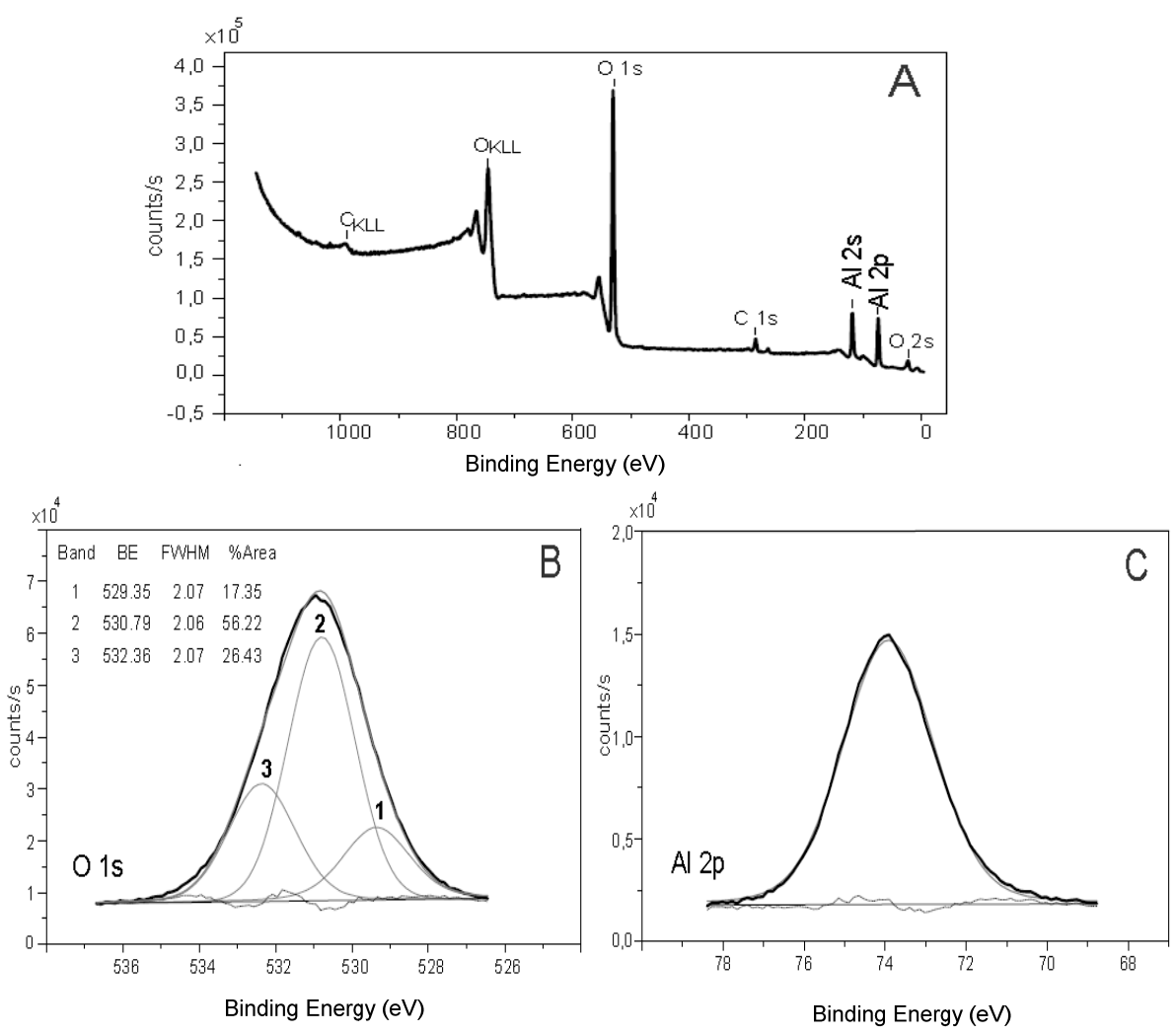

Figura 12: XPS spectra, survey (A), O1s region (B) and Al2p region (C), of AFh sample. 
The binding energy of the photoelectron peaks O1s and A12p are located respectively at $530.96 \mathrm{eV}$ and $73.95 \mathrm{eV}$, and the kinetic energy of the Auger electron peak AlKLL is situated at $1387.64 \mathrm{eV}$, values which are characteristic for aluminium oxides [67]. Trough the fitting procedure, the $\mathrm{O} 1 \mathrm{~s}$ band is found to be composed of three overlapping components, at 529.35 , 530.79 and $532.36 \mathrm{eV}$ with contributions close to 17,56 and $27 \%$, respectively. The lowest energy component is associated to $\mathrm{O}^{2-}$, from oxygen combined with aluminium in the alumina lattice, while the highest band energy component is due to physisorbed water [68]. The main contribution is associated with hydroxyls groups due to water dissociation on the alumina surface. It is known that the $\mathrm{Al}^{3+}$ cations of the alumina surface, as Lewis acid sites, are able to dissociate the water molecules from ambient moisture [69].

The synthesized gamma-alumina fibres are mainly mesoporous, as revealed by nitrogen adsorption-desorption analysis. The isotherms, shown in Fig. 13a, are of type IV and, in general terms, exhibit a hysteresis loop close to $\mathrm{H} 3$ type according to the IUPAC classification [70].
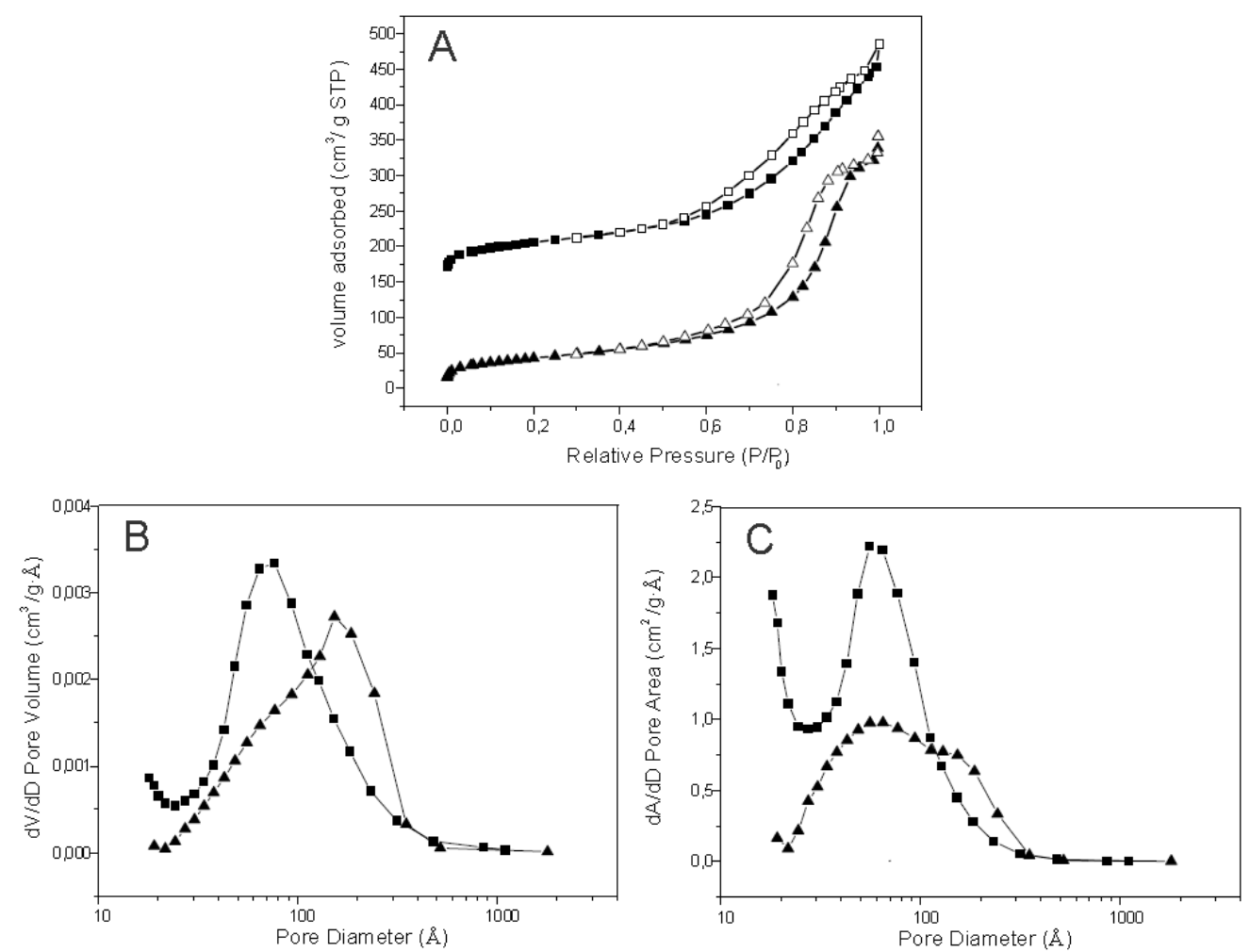

Figure 13: Adsorption-desorption $\mathrm{N}_{2}$ isotherms for $\mathrm{AF}(\boldsymbol{\square})$ and $\mathrm{AFh}(\boldsymbol{\Delta})$ samples (A). The first is moved $150 \mathrm{~cm}^{3} / \mathrm{g}$ from its original position for better viewing. The corresponding pore volume (B) and area (C) distributions. 
AF sample is characterized by a continuous filling of pores as the pressure increases. It is observed a slight restriction at $P / P_{0}$ around 0.97 in which the adsorption and desorption branches are close to overlap. In contrast, two different behaviours can be distinguished in AFh sample between i) $P / P_{0}=0.6$ to 0.75 , where the adsorption is slow, the pore filling is continuous and the hysteresis is close to $\mathrm{H} 3$ type, resembling to AF sample, and ii) $P / P_{0}=0.75$ to 0.95 , where the adsorption capacity increases significantly and both branches are substantially vertical and parallel, overlapping at high relative pressures, thus being the hysteresis loop closer to H1 type. The isotherm of the recalcined sample AFh presents two peculiarities: a steeper slope of the hysteresis loop and a plateau at high relative pressures. The first would be indicative of a more uniform nanostructure and better pore connectivity $[23,71]$ and the second suggests a complete filling of pores, characteristics of a material with a porous structure more organized and with a limited range of pore sizes. In fact, H1 hysteresis type is associated with porous materials consisting of agglomerated particles with a certain compactness and even, it has been associated with cylindrical mesopores open at both ends [72], while the $\mathrm{H} 3$ type, without an adsorption limit at high $P / P_{0}$, is typical of poorly aggregated materials or plate-like particles living rise to slit-shaped pores [70]. The main results of the textural analysis performed are listed in Table 2.

Table 2. Textural data of the ceramic fibers AF and AFh

\begin{tabular}{|l|c|c|}
\cline { 2 - 3 } \multicolumn{1}{c|}{} & AF & AFh \\
\hline$S_{B E T}\left(\mathrm{~m}^{2} / \mathrm{g}\right)$ & 200.8 & 153.9 \\
$C^{a}$ & 118.6 & 108.3 \\
$S t_{\text {Ext }}\left(\mathrm{m}^{2} / \mathrm{g}\right)$ & 174.0 & 144.2 \\
$S t_{\text {micro }}\left(\mathrm{m}^{2} / \mathrm{g}\right)$ & 26.8 & 9.6 \\
$S_{D R}\left(\mathrm{~m}^{2} / \mathrm{g}\right)$ & 203.7 & 131.1 \\
$V s p\left(\mathrm{~cm}^{3} / \mathrm{g}\right)$ & 0.47 & 0.52 \\
$V t_{\text {micro }}\left(\mathrm{cm}^{3} / \mathrm{g}\right)$ & 0.0099 & 0.0028 \\
$V_{D R}\left(\mathrm{~cm}^{3} / \mathrm{g}\right)$ & 0.0816 & 0.0525 \\
$w_{p}{ }^{b}(\AA)$ & 93 & 136 \\
$B J H$ max $(d V / d D){ }^{c}(\AA)$ & 76 & 153 \\
$B J H$ max $(d A / d D)^{c}(\AA)$ & 56 & 56 \\
\hline \multicolumn{2}{|c}{} \\
${ }^{a}$ BET equation constant & \\
${ }^{b}$ Mean pore width, $w_{p}=4 V / S$ \\
${ }^{c}$ Maximum pore size determined by BJH distribution from the adsorption branch
\end{tabular}


Alumina fibres present high external surface area $S t_{E x t}$, very close to the total BET surface area, mainly associated with the existence of mesopores in the range $3-40 \mathrm{~nm}$, as shown BJH distributions in Fig. 13b and Fig. 13c. The surface and volume of micropores accessible to nitrogen, $S t_{\text {micro }}$ and $V t_{\text {micro }}$, are very low in AF sample and practically negligible for $\mathrm{AFh}$, while the surface and volume of those micropores accessible to $\mathrm{CO}_{2}, S_{D R}$ and $V_{D R}$, corresponding to narrow-neck pores, are still significant in AFh sample, values also lower than those exhibited by AF.

The effects on the biomimetic alumina fibres generated by a second calcination step under the presence of moisture consist essentially in modifying the pore volume and area distributions, observed in Fig. 13b and Fig. 13c respectively. An increase in the average pore size, from $9 \mathrm{~nm}$ to $14 \mathrm{~nm}$, could explain the increment of about $11 \%$ in the mesopore volume, Vsp, of AFh sample. This fact would be associated to the destruction of the smaller pores, as the reduction of micropores accessible to $\mathrm{N}_{2}$ and $\mathrm{CO}_{2}$, estimated around 72 and $36 \%$ for $V t_{\text {micro }}$ and $V_{D R}$, respectively (values derived from Table 2), indicates. The micro and nanostructural reorganization experienced by alumina fibres during the recalcination process, resulting in a pore size enlargement and/or in a better pore connectivity, also explains the decrease in specific surface area, which is also consistent with the growh in crystallite size of $\gamma-\mathrm{Al}_{2} \mathrm{O}_{3}$ estimated by the Scherrer equation. The reduction in $S_{B E T}$, $S t_{\text {micro }}$ and $S_{D R}$ values, around 23,64 and $36 \%$ respectively (from Table 2), is associated especially to a decrease in the proportion of pores with a diameter less than $12 \mathrm{~nm}$, as deduced from Fig. 13b.

The morphology, nanostructure and crystallinity of the alumina particles of the AFh fibre walls are analyzed by TEM images and SAED diffraction patterns, collected in Fig. 14. 

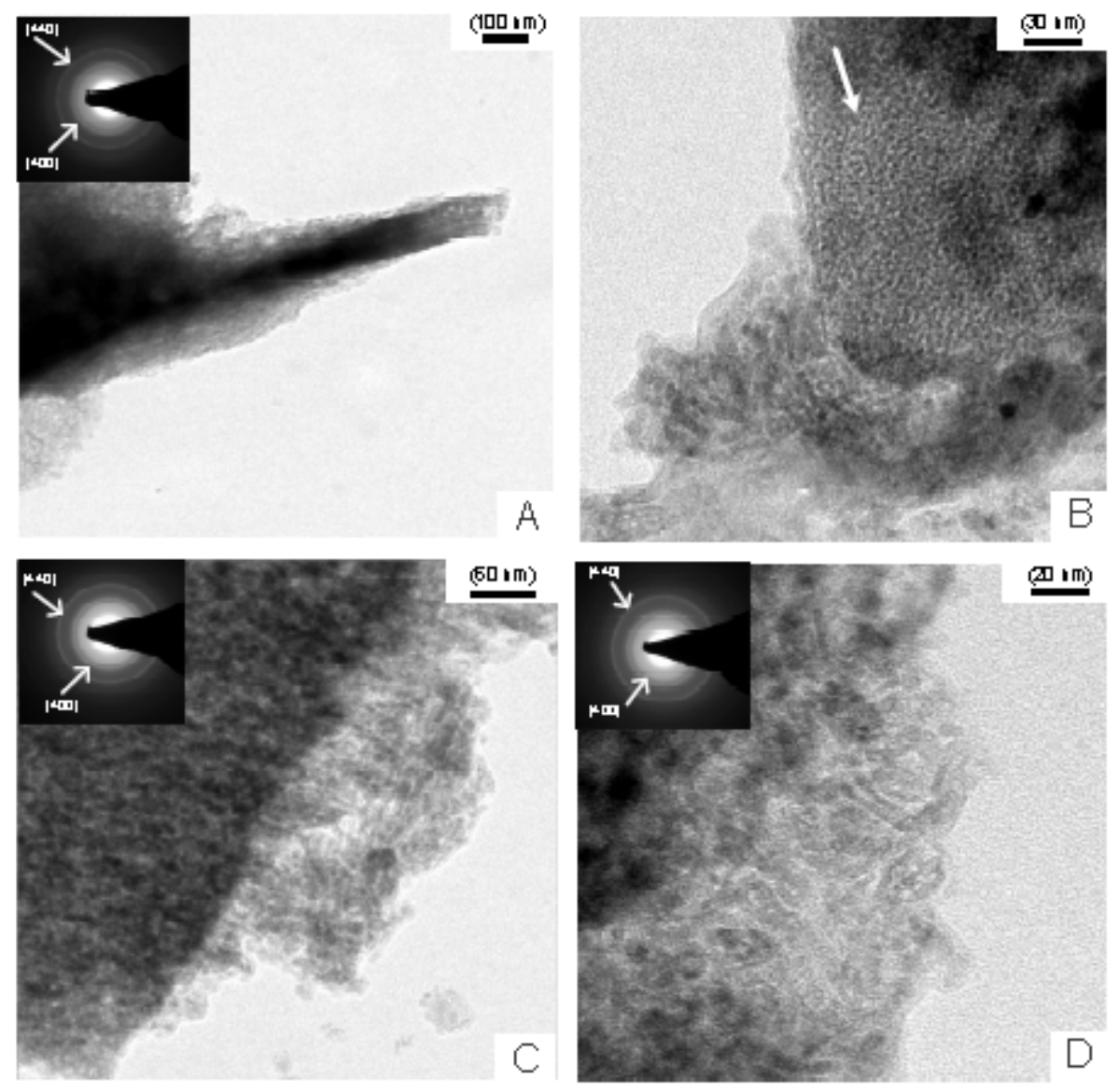

Figure 14: TEM micrographs and SAED patterns of AFh sample.

Alumina fibres presents a spongy texture constituted by aggregated particles, of sizes between 4 and $12 \mathrm{~nm}$, the same order of magnitude as the crystallite estimated by the Scherrer equation. The clusters of particles appear longitudinally arranged in elongated structures, with widths of 120-200 nm, as seen in Fig. 14a. According to XRD, the SAED patterns show a strong polycrystalline habit, where the most intense rings are those associated with the most intense planes of the cubic phase of alumina, (440) and (400). At bigger magnifications, different morphologies can be observed, as the wormhole type shown in Fig. 14b, with particle sizes between 1 and $3 \mathrm{~nm}$ and micropores of average diameters between 1 and $2 \mathrm{~nm}$. Nevertheless, it should be noted that the dominant micromorphology consist of elongate particles, around $15-30 \mathrm{~nm}$ of length and 3-6 nm of width, some of which appear twinned or folded, generating slots of around 2 nm, as can be seen in Fig. 14b-c. 


\section{Conclusions}

Mesoporous gamma alumina fibres with BET surface area of $200 \mathrm{~m}^{2} / \mathrm{g}$ were synthesized through the replica method of sisal fibres, followed by a carbonization process and prolonged calcination at $1000{ }^{\circ} \mathrm{C}$. After a re-calcination stage in wet oxidizing atmosphere, the ceramic fibres are maintained without a significant transformation to $\alpha-\mathrm{Al}_{2} \mathrm{O}_{3}$ phase, reducing specific surface area by around $20 \%$. This stage produces a reorganization of the porous architecture to a more ordered structure, possibly with better connectivity between the pores, together with an increase of the volume and the average size of mesopores, produced at the expense of the loss of microporosity, which explains the decrease of specific surface area.

This paper analyzes the interaction of the aluminium inorganic precursor with the lignocellulosic fibre and its thermal evolution. The interaction between fibre and precursor could take place through the $\mathrm{OH}$ groups of the cellulosic components as well as through the carboxylic groups of the glucuronic acid side chains of the remnant hemicellulose after the alkalizing process. This effect will be studied in greater depth in a later investigation.

As temperature increases, the precursor evolves into amorphous aluminium oxo/hydroxide, which not only covers the surface of the fibre, but becomes part of the walls, due to the precursor infiltration process through the cell walls of the natural fibre, whose final result are alumina ceramic fibres mimicking the natural masks. The slow transformation of the aluminium oxide is associated with the difficulty of nucleation and growth processes during the conformation of the ceramic structure, due to the impediment exerted by the carbonaceous matrix, leading to the formation of low temperature transition alumina crystallites, predominantly $\eta, \gamma-\mathrm{Al}_{2} \mathrm{O}_{3}$, stable at $1000^{\circ} \mathrm{C}$.

\section{Aknowlwdgments}

The author M. Benítez Guerrero wishes to thank the Spanish Consejo Superior de Investigaciones Científicas (CSIC) for the awarding of a JAE pre-doctoral grant. Support from the "Laboratorio de Materiales y Superficies" (CSIC-Univ. Málaga) is acknowledged. 
Financial support from projects CTQ2011-27626 (Spanish Ministerio de Economía y

Competitividad), TEP-7858 (Junta de Andalucía) and FEDER funds is acknowledged.

The authors express their gratitude to Dr. Pilar Pena Castro and to Dr. Antonio H. Aza, from the Instituto de Cerámica y Vidrio (CSIC) in Madrid (Spain), to put at our disposal knowledge, skills and means that have enabled the creation of the present work.

\section{References}

[1] C. Márquez-Álvarez, N. Zilkova, J. Pérez-Pariente, J. Cejka, Catal. Rev., 50 (2008) 222-286.

[2] W. Cai, J. Yu, M. Jaroniec, J. Mater. Chem., 20 (2010) 4587-4594.

[3] S.W. Bian, Y.L. Zhang, H.L. Li, Y. Yu, Y.L. Song, W.G. Song, Microporous Mesoporous Mater., 131 (2010) 289-293.

[4] C. Lesaint, G. Kleppa, D. Arla, W.R. Glomm, G. Oye, Microporous Mesoporous Mater., 119 (2009) 245-251.

[5] Q. Wu, F. Zhang, J. Yang, Q. Li, B. Tu, D. Zhao, Microporous Mesoporous Mater., 143 (2011) 406412.

[6] Z.Y. Yuan, B.L. Su, J. Mater. Chem., 16 (2006) 663-677.

[7] A. Stanislaus, K. Al-Dolama, M. Absi-Halabi, J. Mol. Catal. A: Chem., 181 (2002) 33-39.

[8] Z. Wu, Q. Li, D. Feng, P.A. Webley, D. Zhao, J. Am. Chem. Soc., 132 (2010) 12042-12050.

[9] A.H. Heuer, D.J. Fink, V.J. Laraia, J.L. Arias, P.D. Calvert, K. Kendall, G.L. Messing, J. Blackwell, P.C. Rieke, D.H. Thompson, A.P. Wheeler, A. Veis, A.I. Caplan, Science, 255 (1992) 1098-1105.

[10] A.R. Studart, U.T. Gonzenbach, E. Tervoort, L.J. Gauckler, J. Am. Ceram. Soc., 89 (2006) 17711789.

[11] P. Colombo, Philos. T. Roy. Soc. A, 364 (2006) 109-124.

[12] T.X. Fan, S.K. Chow, D. Zhang, Prog. Mater. Sci., 54 (2009) 542-659.

[13] J. Cao, C.R. Rambo, H. Sieber, Ceram. Int., 30 (2004) 1967-1970.

[14] H. Zhou, T. Fan, D. Zhang, Chem. Sus. Chem., 4 (2011) 1344-1387.

[15] H. Sieber, C. Hoffmann, A. Kaindl, P. Greil, Adv. Eng. Mater., 2 (2000) 105-109.

[16] P. Greil, J. Eur. Ceram. Soc., 21 (2001) 105-118.

[17] M. Singh, J. Martínez-Fernández, A.R. Arellano-López, Curr. Opin. Solid St. M., 7 (2003) 247-254.

[18] M. Singh, B.M. Yee, J. Eur. Ceram. Soc., 24 (2004) 209-217.

[19] F. Vaudry, S. Khodabandeh, M.E. Davis, Chem. Mater., 8 (1996) 1451-1464.

[20] S. Valange, J.L. Guth, F. Kolenda, S. Lacombe, Z. Gabelica, Microporous Mesoporous Mater., 35-36 (2000) 597-607.

[21] S. Acosta, A. Ayral, C. Guizard, L. Cot, J. Sol-Gel Sci. Techn., 8 (1997) 195-199.

[22] Q. Liu, A. Wang, J. Xu, Y. Zhang, X. Wang, T. Zhang, Microporous Mesoporous Mater., 116 (2008) 461-468.

[23] X. Yuan, S. Xu, J. Lü, X. Yan, L. Hu, Q. Xue, Microporous Mesoporous Mater., 138 (2011) 40-44.

[24] J. Cao, C.R. Rambo, H. Sieber, J. Porous Mat., 11 (2004) 163-172.

[25] C.R. Rambo, H. Sieber, Adv. Mater., 17 (2005) 1088-1091.

[26] T.E. Andrade, C.R. Rambo, H. Sieber, A.E. Martinelli, D.M.A. Melo, J. Mater. Sci., 42 (2007) 54265430.

[27] A.N. Shigapov, G.W. Graham, R.W. McCabe, H.K. Plummer Jr, Appl. Catal. A-Gen., 210 (2001) 287-300.

[28] M. Patel, B.K. Padhi, J. Mater. Sci., 25 (1990) 1335-1343.

[29] T. Fan, B. Sun, J. Gu, D. Zhang, L.W.M. Lau, Scripta Mater., 53 (2005) 893-897.

[30] L. Segal, Text. Res. J., 29 (1959) 786-794.

[31] S. Brunauer, P.H. Emmett, E. Teller, J. Am. Chem. Soc., 60 (1938) 309-319.

[32] B.C. Lippens, J.H.d. Boer, J. Catal., 4 (1965) 319-323

[33] E.P. Barrett, L.G. Joyner, P.P. Halenda, J. Am. Chem. Soc., 73 (1951) 373-380.

[34] W.D. Harkins, G. Jura, J. Am. Chem. Soc., 66 (1944) 1366-1373.

[35] J.H.d. Boer, B.C. Lippens, B.G. Linsen, J.C.P. Broekhoff, A.v.d. Heuvel, T.J. Osinga, J. Colloid. Interf. Sci., 21 (1966) 405-414.

[36] M.M. Dubinin, L.V. Radushkevich, Chem. Zentr., 1 (1947) 875-889. 
[37] B.C. Barkakaty, J. Appl. Polym. Sci., 20 (1976) 2921-2940.

[38] L.Y. Mwaikambo, M.P. Ansell, J. Appl. Polym. Sci., 84 (2002) 2222-2234.

[39] D.A. Riesgraf, M.L. May, Appl. Spectrosc., 32 (1978) 362-366.

[40] P. Brand, D. Müller, W. Gessner, Crys. Res. Tehcnol., 2 (1990) 951-956.

[41] C.C. Landry, N. Pappé, M.R. Mason, A.W. Apblett, A.N. Tyler, A.N. MacInnes, A.R. Barron, J. Mater. Chem., 5 (1995) 331-341.

[42] J. Van Den Brand, O. Blajiev, P.C.J. Beentjes, H. Terryn, J.H.W. De Wit, Langmuir, 20 (2004) 6308-6317.

[43] R.H. Marchessault, Pure Appl. Chem., 5 (1962) 107-129.

[44] O. Faix, Fourier Transform Infrared Spectroscopy, in: S.Y. Lin, C.E. Dence (Eds.) Methods in Lignin Chemistry, Springer-Verlag, New York, 1992, pp. 83-109.

[45] Q.A. Nguyen, M.P. Tucker, Dilute acid/metal salt hydrolysis of lignocellulosics, U.S. Patent $6.423 .154,2002$.

[46] L. Liu, J. Sun, C. Cai, S. Wang, H. Pei, J. Zhang, Bioresource Technol., 100 (2009) 5865-5871.

[47] P.E. Sánchez-Jiménez, L.A. Pérez-Maqueda, A. Perejón, J. Pascual-Cosp, M. Benítez-Guerrero, J.M. Criado, Cellulose, 18 (2011) 1487-1498.

[48] P.E. Sánchez-Jiménez, L.A. Pérez-Maqueda, A. Perejón, J.M. Criado, Thermochim. Acta, 552 (2013) 54-59.

[49] F. Suárez-García, A. Martínez-Alonso, J.M.D. Tascón, J. Anal. Appl. Pyrol., 62 (2002) 93-109.

[50] P. Álvarez, R. Santamaría, C. Blanco, M. Granda, J. Anal. Appl. Pyrol., 74 (2005) 337-343.

[51] R. Ball, A.C. McIntosh, J. Brindley, Combust. Theor. Model, 8 (2004) 281-291.

[52] H. Yang, R. Yan, H. Chen, D.H. Lee, C. Zheng, Fuel, 86 (2007) 1781-1788.

[53] H. Barzegar-Bafrooei, T. Ebadzadeh, Adv. Powder Technol., 22 (2011) 366-369.

[54] Y. Repelin, E. Husson, Mat. Res. Bull., 25 (1990) 611-621.

[55] M. Pijolat, M. Dauzat, M. Soustelle, Thermochim. Acta, 122 (1987) 71-77.

[56] R.B. Bagwell, G.L. Messing, J. Am. Ceram. Soc., 82 (1999) 825-832.

[57] H.C. Stumpf, A.S. Russell, J.W. Newsome, C.M. Tucker, Ind. Eng. Chem., 42 (1950) 1398-1403.

[58] R. Tertian, D. Papée, J. Chem. Phys., 55 (1958) 341-353

[59] P. Brand, R. Troschke, H. Weigelt, Cryst. Res. Technol., 24 (1989) 671-675.

[60] T. Yamaguchi, N. Mukouyama, T. Fujita, S. Taruta, K. Kitajima, Ceram. Int., 37 (2011) 201-206.

[61] R.N. Das, A. Bandyopadhyay, S. Bose, J. Am. Ceram. Soc., 84 (2001) 2421-2423.

[62] P. Wang, C. Wang, L. Lin, Y. Zhu, Y. Xie, J. Am. Ceram. Soc., 89 (2006) 2744-2748.

[63] S. Zhou, R.L. Snyder, Acta Cryst. B, 47 (1991) 617-630.

[64] C. Morterra, G. Magnacca, Catal. Today, 27 (1996) 497-532.

[65] C.S. John, N.C.M. Alma, G.R. Hays, Appl. Catal., 6 (1983) 341-346.

[66] C. Pecharromán, I. Sobrados, J.E. Iglesias, T. González-Carreño, J. Sanz, J. Phys. Chem. B, 103 (1999) 6160-6170.

[67] J.F. Moulder, W.F. Stickle, P.E. Sobol, K.D. Bomben, Handbook of X-ray Photoelectron Spectroscopy, Perkin-Elmer Corporation, Physical Electronics Division, 1992.

[68] M.P. Casaletto, G. Mattogno, M.A. Massucci, Appl. Surf. Sci., 211 (2003) 216-226.

[69] M. Trueba, S.P. Trasatti, Eur. J. Inorg. Chem., (2005) 3393-3403.

[70] K.S.W. Sing, D.H. Everett, R.A.W. Haul, L. Moscou, R.A. Pierotti, J. Rouquérol, T. Siemieniewska, Pure Appl. Chem., 57 (1985) 603-619.

[71] S. Handjani, J. Blanchard, E. Marceau, P. Beaunier, M. Che, Microporous Mesoporous Mater., 116 (2008) 14-21.

[72] J.L. Mohanan, S.L. Brock, Chem. Mater., 15 (2003) 2567-2576. 